\title{
When Does Going to the Doctor Serve the Public Health? Medical Monitoring Response Costs Under CERCLA
}

\author{
Dan A. Tanenbaum $\dagger$
}

During the Senate debate on the Comprehensive Environmental Response, Compensation, and Liability Act of 1980 ("CERCLA"), Senator George Mitchell reminded his colleagues of the Act's limited scope:

Under this bill, if a toxic waste discharge injures both a tree and a person, the tree's owner, if it is a government, can promptly recover ... for the cost of repairing the damage, but the person cannot. In effect, at least as to the superfund, it is all right to kill people, but not trees. ${ }^{2}$

Senator Mitchell made his comment in the wake of a broad compromise that allowed CERCLA to pass both houses of Congress. The final bill deleted much of what was to make the Act "comprehensive," including private actions for damages and medical expenses. ${ }^{3}$ The Act that finally was signed into law by President Carter authorizes government cleanup of hazardous waste sites, but does not provide for compensation to those who are physically harmed by hazardous waste. ${ }^{4}$ On its own terms, CERCLA redresses public, not private wrongs.

Congress created CERCLA because other federal laws, including the Resource Conservation and Recovery Act of 1976

† B.A. 1987, The University of Pennsylvania; J.D. Candidate 1992, The University of Chicago.

${ }^{1}$ Pub L No 96-510, 94 Stat 2767 (1980), codified at 42 USC $\$$ 9601-9675 (1988 \& Supp 1991). The Act is known popularly as "Superfund" because it authorizes creation of the Hazardous Substance Response Trust Fund. Because this Comment does not address recoveries under the Fund, it will use the acronym CERCLA exclusively.

2 96th Cong, 2d Sess (Nov 24, 1980), in 126 Cong Rec 30941 (Nov 24, 1980) (statement of Senator Mitchell).

' See Robert C. Eckhardt, The Unfinished Business of Hazardous Waste Control, 33 Baylor L Rev 253, 253 (1981). In 1980, Mr. Eckhardt was chairman of the Oversight and Investigations Subcommittee of the House Interstate and Foreign Commerce Committee, and as such was a participant in the CERCLA debates.

- Exxon Corp. v Hunt, 475 US 355, 375 (1986). 
("RCRA")," were unable to control the mounting environmental threat of hazardous waste disposal sites. ${ }^{6}$ Specifically, none of the federal programs in existence sanctioned the initiation of environmental cleanup or remedial actions, nor could owners of abandoned or inactive sites be held liable for cleanup costs. ${ }^{7}$ Congress needed a stronger statute that would enable the government to clean up waste sites and then recover cleanup costs from the responsible parties. ${ }^{8}$

Under CERCLA, the government has two methods of cleaning up hazardous waste sites. First, it can use money from the Hazardous Substance Response Trust Fund (Superfund) to clean up a hazardous waste site, ${ }^{9}$ and then sue the responsible party or parties to recover the cleanup costs. ${ }^{10}$ Alternatively, when there is an "imminent and substantial endangerment to the public health or welfare or the environment because of an actual or threatened release of a hazardous substance," it can order the private parties responsible for wastes to clean up the site themselves. ${ }^{11}$

CERCLA has no provision that allows private parties to sue for damages for personal injuries. Section 107(a)(4)(B) of the Act nevertheless makes responsible parties liable for "any [ ] necessary costs of response incurred by any other person consistent with the national contingency plan."12 Courts have held that this section authorizes private individuals to clean up hazardous sites on their own and then to recover their expenses from the responsible parties. ${ }^{13}$ This Comment addresses whether private parties can recover medical monitoring costs under $\S 107(a)(4)(B)$. Such suits are brought by parties who wish to assess the effects of hazardous wastes on the environment by monitoring human bodies. This Comment will show that medical monitoring costs are consistent

${ }^{5}$ Pub L No 94-580, 90 Stat 2795 (1976), codified as an amendment to the Solid Waste Disposal Act at 42 USC \$§ 6901-6987 (1988 \& Supp 1991). RCRA allows the EPA to regulate future hazardous waste creation, transportation, storage, and disposal. It applies only to existing hazardous waste sites that become inactive.

${ }^{B}$ S Rep No 96-848, 96th Cong, 2d Sess 11 (1980).

IId at 10-12.

s Id at 12.

- See 42 USC $\$ 9611$.

${ }^{10} 42$ USC $\$ \S 9604(a), 9607(a)$.

${ }^{11} 42$ USC \& 9606(a).

1242 USC $\S 9607(a)(4)(B)$. Subsequent textual references to this provision will be to $\S$ 107(a)(4)(B) of CERCLA.

${ }^{13}$ See, for example, Walls v Waste Resource Corp., 761 F2d 311, 318 (6th Cir 1985); Artesian Water Co. v New Castle County, 851 F2d 643, 648 (3d Cir 1988). 
with CERCLA's statutory purpose and design, and the costs should therefore be granted in actions brought under $\S 107(\mathrm{a})(4)(\mathrm{B})$. It will suggest that private suits, including medical monitoring cost recovery actions, are important enforcement mechanisms that Congress created to further CERCLA's public goals. Finally, the Comment suggests a test that courts can use to identify the most important criteria in medical monitoring suits, and to distinguish genuine suits from frivolous ones.

\section{Medical Monitoring Costs Under CERCLA}

The Senate bill that became CERCLA originally contained a provision for private recovery of medical expenses. ${ }^{14}$ To achieve bipartisan support for the bill, however, Congress deleted all of the Act's express private action provisions. ${ }^{15}$ Medical treatment expenses necessitated by exposure to hazardous wastes thus are not recoverable under CERCLA. The Act does, however, authorize private parties to assist the government's cleanup enterprise. Individuals may clean up waste sites and recover their "necessary costs of response" from the responsible polluters. This Comment argues that medical costs that qualify as response costs-expenses incurred for attempting to clean up a waste site-may be recoverable. Such costs would include medical monitoring costs expended to determine the extent of environmental harms, but would not include expenditures for treating individuals for illnesses caused by those harms.

\section{A. Claims for Medical Monitoring Costs}

A typical private party suit under CERCLA may have many stages. As will be seen below, the first step in a response cost case may be some form of testing. Often, before a party can begin removing hazardous wastes from a site, it must determine the extent of the problem through a series of tests. For instance, in Brewer $v$ Ravan, the plaintiffs sued to recover the costs of "soil testing,

14 S 1480, 96th Cong, 1st Sess (Jul 11, 1979), in 125 Cong Rec 17991 (Jul 11, 1979).

18 There was great debate in Congress over whether CERCLA should be broadly regulatory or very limited in scope. The original House bill was not nearly as ambitious as the Senate version of CERCLA. See text accompanying notes 31-43. See also, for example, Senator Mitchell's remarks: "The guiding principle of those who wrote S. 1480 was that those found responsible for harm caused by chemical contamination should pay for the costs of that harm. We are abandoning that principle ... when the damage involved is to a person." 126 Cong Rec at 30941 (cited in note 2). 
water monitoring, and medical tests and medical screening."16 The court recognized the claim under $\S 107(a)(4)(B)$ (against a summary judgment motion), including the costs for medical testing. ${ }^{17}$

The plaintiffs in Brewer wished to test the health of the local population to determine how far the hazardous waste contamination had spread. It is not clear exactly what procedures were planned because apparently the parties settled the case before the monitoring program could be instituted. It is likely, though, that local residents would have been given complete physical exams on a regular basis, and would have had endocrinological and genetic testing as well. ${ }^{18}$ Tissue samples of people also would have been tested as a way of gauging the effects of the hazardous wastes at varying distances from the actual site. ${ }^{19}$ In effect, the Brewer plaintiffs intended to use medical testing as a tool for preparing a removal action under CERCLA. Plaintiffs like those in Brewer consider medical testing to be a "necessary cost of response."

\section{B. Recovery of Investigatory Costs}

Response costs may include investigatory costs incurred in the initial testing of a contaminated site. Medical monitoring cost suits are more complex than most response cost actions under $\S 107(a)(4)(B)$ of CERCLA because they involve an initial hurdle not present in most cases: whether costs can be recovered before a party actually incurs them. Although courts once were divided on whether such prospective response costs were recoverable under the Act, most courts now read $\S 107(a)(4)(B)$ to permit recovery of prospective response costs, also called investigatory costs. ${ }^{20}$ Courts that uphold investigatory costs look to $\S 101(23)$ of CERCLA

${ }_{16} 680$ F Supp 1176, 1179 (M D Tenn 1988).

17 Id.

${ }_{18}$ These descriptions are for the most part conjectural. For a case in which a court approved a program similar to the one described in the text (albeit for a common law medical damages claim), see Merry $v$ Westinghouse Electric Corp., 684 F Supp 847, 852 (M D Pa 1988). See also Shirley A. Conibear, M.D., Proposed Medical Surveillance For Residents of Gettysburg, PA Whose Water Has Been Contaminated 7-18 (Oct 8, 1987), as referred to in Merry, 684 F Supp at 851 (report on file with U Chi L Rev).

29 Id.

${ }^{20}$ See, for example, Wickland Oil Terminals v ASARCO, Inc., 792 F2d 887, 892 (9th Cir 1986) (expenses for testing groundwater); Artesian Water, 851 F2d at 651 (same); Velsicol Chemical Corp. $v$ Reilly Tar \& Chemical Corp., 15 Envir L Rptr 20103, 20105 (E D Ten 1984) (expenses for determining environmental damage from coal tar sludge deposited in holding tank on property). The Fifth Circuit, however, does allow recovery of investigatory costs. Bulk Distribution Centers v Monsanto Co., 589 F Supp 1437, 1450 (S D Fla 1984) (all expenses must be incurred before they can be recovered). 
which defines removals as "such actions as may be necessary to monitor, assess, and evaluate the release or threat of release of hazardous substances."21 They note that this definition does not distinguish removal costs that already have been incurred from ongoing or future costs in preparation for an action; both types of costs serve the statutory function.

In Artesian Water Co. $v$ New Castle County, ${ }^{22}$ for example, the appellate court affirmed the decision of the district court to award a water company both the costs it had already incurred in cleaning up its wells and the costs necessary to monitor and evaluate the impact of the release of the hazardous substances on surrounding wells. The district court had followed the reasoning of Wickland Oil Terminals v ASARCO, Inc., in which the Ninth Circuit held that "[ $t]$ he distinction . . . between investigatory costs and on-site cleanup costs is immaterial under section 107(a)."23 The reasoning of Wickland Oil and Artesian Water is now the accepted reading of $\S \S 107(a)(4)(B)$ and $101(23){ }^{24}$ Thus, a party can recover response costs not only for past expenditures, but for ongoing and future expenses as well.

\section{Medical Monitoring Costs as Investigatory Costs}

Expenses for monitoring the effects of hazardous wastes on peoples' bodies are consistent with investigatory expenses that courts often grant. Medical monitoring costs must be distinguished from direct medical treatment costs. As noted earlier, Congress unambiguously removed recovery of costs incurred for medical treatment from CERCLA before its passage. Nevertheless, this Comment argues that costs for monitoring medical symptoms caused by hazardous waste releases ${ }^{25}$ can be characterized as investigatory costs, and therefore are recoverable under $\S 107(\mathrm{a})(4)(\mathrm{B}) .^{26}$

2142 USC \$ 9601(23) (emphasis added).

22851 F2d at 644-45.

2s 792 F2d at 892 .

${ }^{24}$ See text accompanying note 20 . The Fifth Circuit is the one possible holdout, see id, though it has never had an appellate decision on point.

${ }^{26}$ CERCLA defines "release" as "any spilling, leaking, pumping, pouring ... or disposing [of hazardous wastes] into the environment . . ." 42 USC \& 9601(22).

${ }^{28}$ A recent case has raised the possibility of permitting medical monitoring costs only when they have already been expended. See Cook v Rockwell International Corp., $755 \mathrm{~F}$ Supp 1468 (D Colo 1991) ("If plaintiffs have incurred no cognizable response costs, it is appropriate to ... [dismiss] the CERCLA claim at the outset."). This appears to be the only case to use this approach. 
These monitoring costs are not a form of reimbursement for personal harms, but are "costs of response" that are incurred by parties who test the extent of the environmental harm as a prelude to cleaning up a waste site.

\section{CERCLA's PuRpose AND Design}

When a court decides whether to permit recovery for medical monitoring costs-or any other response cost-under $\S 107(\mathrm{a})(4)(\mathrm{B})$, it must determine whether a recovery would comport with the purposes of a statute that is "not a paradigm of clarity or precision." $" 27$ In interpreting the specific provisions of CERCLA, a court must thus synthesize various strands of meaning. Nevertheless, many of the goals and purposes of the Act (such as forcing polluters to pay the costs of cleanups) were expressed clearly. Congress merely left ambiguous its preferred methods of achieving those goals. The courts' ultimate role, then, is to decide whether medical monitoring costs are a reasonable means of furthering the Act's broad purposes.

This section will discuss CERCLA's legislative history and purpose, and will outline the Act's design. It will show that CERCLA was enacted with a broad "public health" purpose, and that $\S 107(\mathrm{a})(4)(\mathrm{B})$ was designed to allow private parties to further the Act's broad goals. It then will discuss the roles the government and private litigants play in achieving those goals.

\section{A. CERCLA's Legislative History}

The congressional background of CERCLA is one of compromise. The purpose of many specific provisions is often unclear because much of the congressional debate focused on provisions that ultimately were not included in the statute, and because the Act was passed under a bipartisan agreement that excluded meaningful floor debate. ${ }^{28}$ In fact, Congress salvaged the Act from at least three different bills that had failed to pass. ${ }^{29} \mathrm{~A}$ lame duck Congress

${ }^{27}$ See Artesian Water, 851 F2d at 648.

28 126 Cong Rec at 30916 (cited in note 2) (statement of Senator Byrd) ("We have come to the conclusion, based on their desire as well as ours to achieve a feasible solution, considering the time constraints and other factors, that Senator B[aker] and I will cosponsor the amendment that has been worked out and that we will oppose any amendments thereto."). For a narrative history of CERCLA's legislative background, see Frank P. Grad, A Legislative History of The Comprehensive Environmental Response, Compensation and Liability Act of 1980, 8 Colum J Envir L 1 (1982).

${ }^{29}$ Most notably, HR 85, 96th Cong, 2d Sess (Aug 27, 1980), in 126 Cong Rec 23567 (Aug 27, 1980); HR 7020, 96th Cong, 2d Sess (Apr 2, 1980), in 126 Cong Rec 25894 (Sep 17, 
hastily assembled it, fearing that the incoming President would not support any environmental legislation that required new federal expenditures..$^{30}$ Despite these uncertainties regarding the act's passage, however, one can interpret CERCLA's response cost provision using two relevant guides: the general purpose of the Act and the specific purpose of that provision. The broad purpose of the Act is to clean up the environment for the public good; the narrower purpose of the response cost section is to facilitate that broad goal through private activities.

1. The broad purpose of the Act.

The Senate report that accompanied CERCLA's passage began:

Modern chemical technology has produced miracles which have greatly improved this Nation's standard of living. But the increased generation of hazardous substances associated with these new products has proved to be a serious threat to our Nation's public health and environment. ${ }^{31}$

The Senate felt that it must take strong measures to protect such abstract concepts as the "public health" and the "environment." The broad purpose of the Act addresses those concerns. ${ }^{32}$ CERCLA serves the public good; it is oriented to the public law aspects of environmental regulation. It is not concerned with an individual's health or with damages to individuals' property.

The Act's purpose must also be viewed in light of Congress's desire to address many of the problems faced by society as a whole as a result of chemical contamination. ${ }^{33}$ For example, the Senate report noted many dramatic ecological disasters (such as the "Valley of the Drums" in Kentucky and the Love Canal debacle in New

1980); S 1480, 96th Cong, 2d Sess (Nov 24, 1980), in 126 Cong Rec 30898 (Nov 24, 1980). S 1480 nominally was passed and became CERCLA, but the final version was drastically different from the original. Grad, 8 Colum $J$ Envir L at 1 (cited in note 28).

${ }^{30}$ Grad, 8 Colum $J$ Envir $L$ at 19 (cited in note 28). Ronald Reagan's election to the White House necessitated the last-minute compromise that limited CERCLA's scope as well as its budget. The lame duck President and Congress worked quickly to pass a hazardous waste cleanup law before Reagan would take office.

${ }^{31} \mathrm{~S}$ Rep No $96-848$ at 2 (cited in note 6).

32 For example, $\$ 106(a)$ empowers the government to take emergency actions in the case of "imminent and substantial endangerment to the public health." 42 USC $\S 9606$ (a) (emphasis added).

s3 $\mathrm{S}$ Rep No $96-848$ at 10-12 (cited in note 6). 
York) that adversely affected entire communities. ${ }^{34}$ To help achieve the goal of protecting society as a whole, Congress established strict liability to ensure that responsible parties would bear the costs of the damage they cause to society. ${ }^{35}$

2. The purpose of the private response cost provision.

The private-party response cost provision of $\S 107(\mathrm{a})(4)(\mathrm{B})$ has a specific, more defined purpose. Like the rest of the Act, it arose from compromise: Congress dropped provisions permitting private actions for damages, but retained provisions providing for privately-initiated cleanup actions. The first bill to resemble what was to become CERCLA, the Senate's "Environmental Emergency Response Act" ${ }^{36}$ had covered both private cleanup actions and private damages suits. Included in that bill, S 1480, were provisions for victim compensation for economic and medical damages, in addition to a scheme of government and private-party responses to hazardous waste emergencies. ${ }^{37}$ The bill's victim compensation sections were limited, ${ }^{38}$ but their inclusion shows that the Senate considered creating a federal "toxic tort" to bridge the gap between public protection and private compensation. More importantly, though, was the private response cost provision. S 1480 originally was drafted to permit private parties to recover for damages to their persons and property and also for costs of cleaning up on their own as an enforcement mechanism for the overall goal of cleaning up the environment. In the compromise that passed, the latter scheme was retained as $\S 107(a)(4)(B)$.

${ }^{36}$ Id.

${ }^{35}$ Id at 13.

${ }^{36} \mathrm{~S} 1480$, 96th Cong, 1st Sess (Jul 11, 1979), in 125 Cong Rec 17988 (Jul 11, 1979).

${ }^{37}$ See id at 17991.

${ }^{38}$ As proposed on the Senate floor, $\S 4(a)(2)$ of the bill was to provide for:

(2) all damages for economic loss or loss due to personal injury or loss of natural resources resulting from [ ] a discharge, release, or disposal, including-

(A) any injury to, destruction of, or loss of any real or personal property, including relocation costs;

..

(E) any loss of income or profits or impairment of earning capacity resulting from injury to or destruction of real or personal property or natural resources ...

(F) all out-of-pocket medical expenses, including rehabilitation costs, due to personal injury ....

Id. After the committee considered the bill, the compensation scheme was limited to recovery only for (1) all medical expenses and (2) $100 \%$ of lost wages for the first year of injury and $80 \%$ of lost wages for the second year. See S 1480, §§ 4(a), 4(c), 4(n) (cited in note 29); S Rep No 96-848 at 23 (cited in note 6). 
The House's alternative to the Senate bill was more limited. The House considered a bill to amend RCRA, entitled the "Hazardous Waste Act of 1980."39 This bill included provisions for regulating hazardous waste sites via reporting, cleanup, and monitoring, ${ }^{40}$ but allowed cost reimbursement only for governmental authorities. ${ }^{41}$ The House bill did not contain any provisions for compensating victims and also excluded private party cleanup-cost actions. The House bill, in contrast to the early Senate versions of CERCLA, focused completely on the government's role in hazardous waste cleanups.

In the final compromise bill, the Senate removed the victim compensation sections, but retained the private right of action for recovering response costs in $\S 107(a)(4)(B) .^{42}$ The discussion on the Senate floor focused on what was cut and glossed over what was left intact, ${ }^{43}$ but it is uncontroverted that the Senate rejected the House's attempt to deny private parties a role in cleanups. The Senate bill had always included the scheme for allowing private enforcement of the public goal of cleaning up the environment, and this scheme passed into law. The retention of the private enforcement mechanism in the wake of other great compromises is the starting point for evaluating private actions under CERCLA.

The legislative history elucidates two points crucial to considering the issue of medical monitoring costs. First, CERCLA has a very broad, public-minded purpose. All of the Act's sections must be construed against this standard. Response cost actions, therefore, should be favored if they can advance the Act's broad purpose of protecting the "public health." Second, and more importantly for the purposes of this Comment, Congress made many compromises, but never cut the private right to recover response costs. Though it never spelled out clearly its desired means for accomplishing CERCLA's broad goals, Congress left private actions available. Based on a construction of the legislative history discussed above, this Comment contends that medical monitoring suits, like all cost recovery suits under $\S 107(a)(4)(B)$, are a viable, if underutilized, tool for achieving CERCLA's purposes.

39 $\mathrm{HR} 7020,126$ Cong Rec at 25894 (cited in note 29). Representative Florio introduced the original bill to the House. HR 7020, 96th Cong, 2d Sess (Apr 2, 1980), in 126 Cong Rec 7490 (Apr 2, 1980).

10 See HR Rep No 96-1016, Part I, 96th Cong, 2d Sess 3-6 (1980).

11 HR 7020, § 5(a), 126 Cong Rec H9459 (daily ed, Sep 23, 1980).

${ }^{2}$ See 42 USC \& 9607(a)(4)(B).

13 See Senator Mitchell's remarks in note 15, for example. 


\section{B. How CERCLA Works}

CERCLA is designed to force responsible parties to pay for hazardous waste cleanups. ${ }^{44}$ The chief means of achieving that goal has been, and likely will continue to be, actions initiated and carried out by the federal government. Although CERCLA includes a provision for private individuals to clean up others' waste sites and recover their costs of doing so, the focus of the Act is government action. ${ }^{45}$ Some have called the Act a "shovels first, lawyers later" statute because of its emphasis on action followed by litigation, ${ }^{46}$ but generally the lawyers (and very often the shovels) have belonged to federal agencies. ${ }^{47}$ This section first will outline the role of federal agencies in enforcing CERCLA's mandate. It then will discuss the role of private parties in completing that enforcement scheme.

1. The role of the EPA.

The Environmental Protection Agency ("EPA") implements most CERCLA programs. ${ }^{48}$ The EPA can use money from the Superfund to clean up hazardous waste sites, ${ }^{49}$ and then replenish the fund by suing the responsible parties to recover its costs. ${ }^{50} \mathrm{Al}-$ ternatively, the EPA can order private parties to clean up sites themselves when there is an "imminent and substantial endangerment to the public . . . welfare or the environment because of an actual or threatened release of a hazardous substance." ${ }^{\text {"51 }}$ EPA activities are the focal point of CERCLA enforcement.

"See S Rep No 96-848 at 13 (cited in note 6).

45 USC $\$ 9604$.

48 Paraphrasing comments of EPA assistant administrator Eckhardt C. Beck, quoted in Steven Cohen, Defusing the Toxic Time Bomb: Federal Hazardous Waste Programs, in Norman J. Vig and Michael E. Kraft, eds, Environmental Policy in the 1980's: Reagan's New Agenda 282 (CQ Press, 1984).

47 Generally the EPA tries to get responsible parties to perform cleanups on their own so that federal Superfund money need not be expended. Even under a best case scenario, however, the federal government must expend resources to initiate the private clean up.

13 CERCLA authorizes the President to take actions, but the President may delegate those powers. See 42 USC $\S \S 9611,9615$. President Reagan delegated much of his authority to federal agencies, including the EPA. See Exec Order No 12,316, 3 CFR 168 (1981), as amended by Exec Order No 12,418, 3 CFR 187 (1983).

49 See 42 USC \$\$ 9604, 9611.

so 42 USC $\$ 9607$.

s1 42 USC \& 9606(a). 
2. The role of the ATSDR.

Medical monitoring cost cases raise issues involving another federal agency that performs CERCLA duties, the Agency for Toxic Substances and Disease Registry ("ATSDR"). ${ }^{52}$ In $\S$ 104(i) of CERCLA, Congress established the ATSDR and charged it with studying the health effects of hazardous substances. ${ }^{53}$ In the 1986 amendments to CERCLA, Congress greatly expanded the ATSDR's role and responsibilities under the Act, and mandated specific procedures for it to follow. ${ }^{54}$ The ATSDR's activities now include general research and assessment of the impact of toxic chemicals on health, as well as health studies at specific hazardous waste sites. ${ }^{55}$ The ATSDR is charged with conducting health assessments at sites on, or proposed for placement on, the EPA's National Priority List. ${ }^{56}$ In addition, the ATSDR may provide medical care and medical testing in cases of public emergency where there has been exposure to toxic chemicals. ${ }^{57}$

It may appear that the ATSDR's duties overlap with, or even preclude the need for, private medical monitoring suits. After all, the agency must assess "the potential risk to human health posed by individual sites and facilities. ..." 58 However, the ATSDR currently performs health assessments only at sites already targeted by the EPA - those sites listed on the NPL. ${ }^{59}$ Moreover, its duties are distinct from the monitoring performed by private parties in preparation for removal actions. ${ }^{\circ 0}$ While the ATSDR can serve as a model for private monitoring programs, its existence does not preclude those monitoring programs.

3242 USC \& 9604(i).

53 Although CERCLA authorized the creation of the ATSDR in 1980, Congress did not establish the agency until 1983. See Martin R. Siegel, Integrating Public Health Into Superfund: What Has Been the Impact of the Agency for Toxic Substances and Disease Registry?, 20 Envir L Rptr 10013, 10013-14 (1990).

s4 Id at 10013. The ATSDR's responsibilities now include: 1) preparation of a list of at least 100 substances commonly found at hazardous sites; 2) preparation of "toxicological profiles" of these substances; 3) initiation of a research program for substances for which there is insufficient data; and 4) performance of "health assessments" to determine whether human exposure to such substances should be minimized. 42 USC \$§ 9604(i)(1), 9604(i)(2), 9604(i)(3), 9604(i)(5), 9604(i)(6).

${ }^{\text {Bs }} 42$ USC \$ 9604(i)(6).

sB Id.

${ }^{37} 42$ USC $\S 9601(\mathrm{i})(1)(D)$.

ss 42 USC $\$ 9604(\mathrm{i})(6)(\mathrm{F})$.

${ }^{39}$ See Siegel, 20 Envir L Rptr at 10016-18 (cited in note 53).

${ }^{\text {Bo }}$ See Section IV.C. 
3. The role of private parties-standards for private recovery under section 107(a)(4)(B).

There is a third method of CERCLA cleanup, one that does not involve federal actions: the private party response cost action. The main hurdles that a plaintiff in a private response cost action must overcome appear in the words of the statute. First, costs that are incurred must be "consistent with the national contingency plan"; second, the response costs must be "necessary"; and third, the plaintiff cannot be responsible for creating the toxic site but must be "any other person." These three requirements are the express starting points for any response cost recovery suit under CERCLA. They must be addressed before examining the specific issues involved in suits for medical monitoring costs.

a) Consistency. First, the private party's costs must be consistent with the National Contingency Plan ("NCP"). The $\mathrm{NCP}$, a set of regulations promulgated by the EPA, ${ }^{62}$ guides government responses to hazardous waste emergencies. One of the EPA's duties under the NCP was the creation of a National Priorities List of sites that pose the greatest danger and that are most in need of permanent, remedial actions. ${ }^{63}$ Although courts once struggled in determining what it means for a party's costs to be "consistent with" the NCP, ${ }^{64}$ the answer is now fairly easy: the most recent version of the NCP has a section titled "other party responses" that helps define the meaning of that previously ambiguous phrase. ${ }^{65}$

${ }^{61} 42$ USC $\$ 9607$ (a)(4)(B) (emphasis added).

${ }_{62} 42$ USC \$ 9605(a). Actually, the President must "establish procedures and standards for responding to releases of hazardous substances." President Reagan delegated this responsibility to the EPA. See note 48 . The NCP is codified at 40 CFR $\S 300.1$ (1991).

${ }^{63} 42$ USC $\S \S 105(\mathrm{~g}), 105(\mathrm{f}) ; 40$ CFR Part 300, App B (1991) (National Priorities List (By Rank) Feb 1991).

${ }^{64}$ For cases reading the consistency requirement liberally, see Pinole Point Properties, Inc. $v$ Bethlehem Steel Corp., 596 F Supp 283, 290 (N D Cal 1984) (at the pleadings stage, "consistency with the NCP . . . does not require federal pre-authorization or supervision"); City of Philadelphia v Stepan Chemical Co., 544 F Supp 1135, 1144 n 16 (E D Pa 1982) ("the question of compliance with the ... [NCP] appears to be related to the recovery of damages and not to the existence of a valid claim for relief'). For a case holding the consistency requirement to be a significant hurdle, see Bulk Distribution Centers, 589 F Supp at 1446 ("without an approved plan, there can be no . . . clean-up effort consistent with the NCP").

${ }^{65}$ See 40 CFR $\S \S 300.700(c)(3)(i), 300.700(c)(3)(i i)$ :

(i) A private party response action will be considered "consistent with the NCP" if the action . . . is in substantial compliance with .... [the regulations] and results in a CERCLA-quality cleanup; (ii) Any response action carried out in compliance with the 
b) Necessary. Although the NCP has clarified the meaning of "consistency," the question of what constitute "necessary costs of response" is harder to answer. CERCLA never defines "necessary" or "costs of response." However, CERCLA does define "response" to mean "removal, remedy, and remedial action." 66 "Removal," in turn, includes "such actions as may be necessary taken [sic] in the event of the threat of release of hazardous substances into the environment ... to monitor, assess, and evaluate the release or threat of release ... to prevent, minimize, or mitigate damage to the public health or welfare or to the environment. ..."67 And "remedy" or "remedial action" means "those actions consistent with permanent remedy taken instead of or in addition to removal actions. ..." they define "necessary costs of response" by using the word "necessary."

Because CERCLA offers little guidance regarding the purpose or scope of the response cost provision, it is not surprising that this issue must be litigated in almost every case. In fact, broadly speaking this Comment is an attempt to decide whether medical monitoring costs are a "necessary" cost of response under CERCLA. The "necessary" issue is at the heart of this and every other $\S 107(\mathrm{a})(4)(\mathrm{B})$ cost recovery action.

c) Other party. Some courts have read the literal words of the statute to include a final burden. They have held that $\S 107(a)(4)(B)$ plaintiffs must not be among the class of "potentially responsible parties" who could be liable for the release. ${ }^{69}$ While this issue is important in the hotly contested areas of lender and transporter liability ${ }^{70}$ under CERCLA, it is a minor point in cases for medical monitoring costs. Parties who bring medical monitoring suits generally are innocent injured parties and do not own the land at issue, and are thus "other parties". For instance, in each of the eight medical monitoring cases considered in Section

terms of an order issued by EPA pursuant to section 106 of CERCLA, or a consent decree ... will be considered "consistent with the NCP."

so 42 USC \& 9601(25).

${ }^{87} 42$ USC § 9601(23).

68 42 USC \& 9601(24).

69 The seminal case is Stepan Chemical, 544 F Supp at 1141-42. While the court in Stepan allowed the city to sue despite its ownership of the landfill at issue, it indicated that a party responsible for dumping would not be allowed to sue. Id.

${ }^{70}$ See, for example, Note, Developments in the Law: Toxic Waste Litigation, 99 Harv L Rev 1458 (1986). 
III below, the suit was brought by citizens groups and/or neighboring landowners who could not be considered potentially responsible parties.

\section{Medical Monitoring Costs Cases in the Courts}

Medical monitoring cost cases under CERCLA are a recent innovation. To date no federal appellate court has decided a case involving medical monitoring costs, and the district court cases that have addressed the issue have been at the summary judgment stage. No court has awarded medical monitoring costs; those courts that have denied the costs often have treated the suits as actions for medical treatment expenses. This section nevertheless will consider the rationales of the district courts that have argued in favor and against medical monitoring costs.

The first court to consider carefully whether medical monitoring costs should be awarded rejected them outright. In Chaplin $v$ Exxon Co., ${ }^{71}$ the district court used three rationales for granting summary judgment against a request for medical monitoring response costs. First, the court noted that "[t]he legislative history reveals the specific omission of such private rights from the final version [of CERCLA]." "72 The court also noted that the ATSDR had the exclusive responsibility for medical monitoring:

Although CERCLA does not ignore medical concerns, such medical care provisions are separate from the liability provisions of Section 9607. Specifically, Congress created the [ATSDR] in Section 104(i) of CERCLA to provide medical care and testing to exposed individuals $\ldots .^{73}$

Finally, the court held that the plaintiffs' complaint did not " 'affirmatively demonstrate that [they had] incurred necessary costs of response." "74 That is, it rejected medical monitoring costs because of their prospective nature. Courts that refuse to grant reimburse-

7125 Envir Rptr (BNA) 2009 (S D Tex 1986). Actually, the first case to deal with medical costs was Jones $v$ Inmont Corp., 584 F Supp 1425 (S D Ohio 1984), in which a suit for investigatory expenses, including medical monitoring costs, was allowed to proceed against a summary judgment motion. Because it did not specifically comment on the propriety of medical monitoring costs, it is not clear, however, how carefully the district court considered the inclusion of medical monitoring costs.

${ }^{2}$ Chaplin, 25 Envir Rptr (BNA) at 2011 (emphasis added).

${ }^{73} \mathrm{Id}$ at 2012.

${ }^{74}$ Id at 2013 (quoting Levin Metals Corp. v Parr-Richmond Terminal Co., 608 F Supp 1272, 1275 (N D Cal 1985)). 
ment of medical monitoring costs continue to rely on these three arguments. ${ }^{75}$ They will be considered carefully below.

In contrast, a number of courts have rejected the arguments made in Chaplin and its progeny and have viewed medical monitoring expenses more favorably. ${ }^{76}$ As noted above, no court has yet affirmatively awarded medical response costs, but the reasoning of certain courts at the summary judgment stage indicates that those courts likely would allow for the recovery of such costs. One such case is Brewer v Ravan. In Brewer, the court agreed with Chaplin that: "CERCLA's legislative history clearly indicates that medical expenses incurred in the treatment of personal injuries or disease caused by an unlawful release or discharge of hazardous substances are not recoverable under section 9607(a)." ${ }^{\prime 77}$ However, the Brewer court went on to distinguish its reasoning from Chaplin's:

To the extent that plaintiffs seek to recover the cost of medical testing and screening conducted to assess the effect of the release or discharge on public health or to identify potential public health problems presented by the release, however, they present a cognizable claim under section 9607(a)..$^{78}$

Thus the court rejected claims for medical treatment expenses, but recognized that medical testing could be a part of a program furthering CERCLA's broad purpose to aid the "public health." The Brewer court accepted the plaintiffs' contention that medical monitoring costs were potentially a permissible use of $\S 107(a)(4)(B)$ to further that broad purpose.

Chaplin and Brewer show that the conflict in the courts is both fundamental and significant: the conflict centers around the characterization of the claims. Some courts characterize the plaintiff's' claims not as investigatory response cost actions, but as suits to recover medical damages. These courts reject monitoring costs

${ }^{75}$ For a sampling of courts essentially following Chaplin's lead, see Wehner $v$ Syntex Corp., 681 F Supp 651, 653 (N D Cal 1987); Coburn v Sun Chemical Corp., 28 Envir Rptr (BNA) 1665, 1668-69 (E D Pa 1988); Lutz v Chromatex, Inc., 718 F Supp 413, 418 (M D Pa 1989); Werlein v United States, 746 F Supp 887, 903 (D Minn 1990).

76 Brewer, 680 F Supp at 1179; Inmont, 584 F Supp at 1429-30; SEPTA, 24 Envir Rptr (BNA) at 1863.

${ }^{77} 680 \mathrm{~F}$ Supp at 1179 (emphasis in original).

${ }^{78}$ Id (emphasis in original). For courts that expressly follow Brewer or employ similar reasoning, see Lykins v Westinghouse Electric Corp., 27 Envir Rptr (BNA) 1590, 1594 (E D Ky 1988); Williams v Allied Automotive, 28 Envir Rptr (BNA) 1223 (N D Ohio 1988). Brewer is not the first case to argue that medical monitoring costs are permissible response costs under $\S 107(a)(4)(B)$, but it explores the issue the most thoroughly. For earlier cases permitting medical monitoring expenses with little discussion, see Inmont, $584 \mathrm{~F}$ Supp at 1429-30; SEPTA, 24 Envir Rptr (BNA) at 1863. 
as a matter of course. The courts that are more receptive to allowing recovery of medical monitoring costs distinguish monitoring from treatment, and maintain that medical monitoring may be a viable investigatory cost under CERCLA. As the next section argues, the latter courts both read the Act and characterize the claims correctly.

\section{Medical Monitoring Costs and CERCLA's PuRposes}

The key question courts face when deciding whether to permit a private recovery of medical monitoring costs under $\S 107(\mathrm{a})(4)(B)$ of CERCLA is whether such a recovery would further the Act's purposes in a manner consistent with the statutory framework. Part A of this section suggests that courts can answer this question correctly only if they understand medical monitoring suits as suits for response costs. Part B introduces an additional complication: the federal government's problems in enforcing CERCLA. If the federal government were administering CERCLA effectively, enforcement questions might be more easily answered: involvement by other parties could be minimized to avoid wasteful, duplicitous suits. Yet, as will be seen below, sites are not being cleaned up fast enough when they are being cleaned up at all.

This section concludes, in Part $\mathrm{C}$, that medical monitoring costs further CERCLA's purposes in a manner consistent with the Act's framework. Medical monitoring suits are private enforcement mechanisms that serve the public good efficiently; they can compensate for the federal government's problems in enforcing CERCLA. Because Congress designed the Act to allow for the use of public and private resources to further the broad public purpose of environmental cleanup, and because the government has been less than successful in this regard, courts should make presumptions in favor of private enforcement actions. ${ }^{79}$ Expanding the private role is the best way to effectuate CERCLA's broad purpose: cleaning up hazardous wastes for everyone's benefit. ${ }^{80}$

79 One commentator has noted the problems in federal administration of CERCLA, and has argued in favor of an expanded state role in the Act's enforcement. See Comment, Expanding State Initiation and Enforcement Under Superfund, 57 U Chi L Rev 985, 986 (1990). Yet while the federal government has budgetary and organizational constraints, so do the states. Creating a presumption in favor of citizen suits and allowing more of them would relieve burdens from both the federal and state governments.

so I do not mean to argue that every time a federal statute is not working well government enforcement should be turned over to private actors. Nevertheless, CERCLA does have a private enforcement provision built in, and its increased use will facilitate better CERCLA implementation. 
A. Characterizing Medical Monitoring Costs in the Courts

The chief difference between the courts that reject claims for recovery of medical monitoring costs and those that do not is the way they characterize the claims at the outset. Courts such as the one in Chaplin understand medical monitoring suits to be an attempt to recover medical damages. ${ }^{81}$ But in cases such as Brewer, the courts construe the suit differently. ${ }^{82}$ They see a meaningful difference between medical expenses for treatment and medical monitoring costs. Thus they are inclined to consider the plaintiffs' arguments and allow recovery of those costs. This Comment argues that the view in Brewer and its progeny better serves CERCLA's purposes.

\section{Chaplin.}

In Chaplin $v$ Exxon Corp., the court held that medical expenses could not be recovered under $\S 107(a)(4)(B)$ because Congress intended to remove provisions for their recovery from the final CERCLA bill. ${ }^{83}$ The Chaplin court focused on Congress's removal of the private right of action for personal damages from the final bill. The court thus seemed to confuse private recovery of treatment expenses with recovery of monitoring expenses for the public purpose of cleaning up the environment. ${ }^{84}$ As was seen above, CERCLA does not authorize private damage suits, but it does permit cost recoveries for the broader public good of environmental cleanup. The Chaplin court thus mischaracterized the suit from the outset. Its subsequent legal arguments were tainted by its initial misstep.

The Chaplin court in fact contradicted its first point by later invoking the existence of the ATSDR. By arguing that medical monitoring costs should be administered by the ATSDR, the Chaplin court implicitly admitted that the issue was medical testing, and not medical treatment, thus contradicting its first point. Moreover, the argument that the ATSDR should control all medical testing procedures was wrong substantively, because the agency has come to be used solely in remedial actions performed by the

si See text accompanying notes 83-87.

${ }^{82}$ See text accompanying notes 88-89.

8325 Envir Rptr (BNA) at 2011.

s4 Id. 
EPA and has not been connected to private actions for response costs. ${ }^{85}$

The Chaplin court used a third argument against medical monitoring, namely that investigatory costs are not "affirmative showings" of response costs. ${ }^{86}$ This point is wrong if cases such as Wickland Oil and Artesian Water-which represent the nearly unanimous position that ongoing and future monitoring costs may be recovered under $\S 107(\mathrm{a})(4)(\mathrm{B})$ as investigatory costs-are to be followed. ${ }^{87}$ In light of these precedents, the Chaplin court offered no good reasons to distinguish medical monitoring costs from other investigatory expenses. As long as medical monitoring is a useful part of private cleanup actions, it presumably should be treated the same way as other investigatory costs. The Chaplin court's reaction showed its disfavor of all private response cost actions.

\section{Brewer.}

The court in Brewer $v$ Ravan distinguished its reasoning from the Chaplin court's views. ${ }^{88}$ The Brewer court saw a crucial difference between "public health" and "personal injuries or disease," which mirrors Congress's compromise in establishing $\S 107(\mathrm{a})(4)(\mathrm{B})$. The court permitted the plaintiff's claim for medical monitoring costs to proceed past summary judgment, and allowed the plaintiffs to recover costs of medical testing, because that testing served to protect the public at large from the ill effects of hazardous substance releases. ${ }^{89}$ In so doing, the Brewer court avoided the Chaplin court's mistake of mischaracterizing the claim. The court also did not invoke the ATSDR nor did it limit the scope of investigatory cost recoveries. The court realized that individual remedies are beyond CERCLA's scope, but that the Act does permit private actions to protect the environment and the health of the population at large.

${ }^{85}$ See Section II.B.2.

86 25 Envir Rptr (BNA) at 2013 (quoting Levin Metals Corp. v Parr-Richmond Terminál Corp., 608 F Supp 1272, 1275 (N D Cal 1985)).

${ }^{87}$ See text accompanying notes 22-23.

8s Brewer, 680 F Supp at 1179.

89 Id ("To the extent that plaintiffs seek to recover the cost of medical testing and screening conducted to assess the effect of the release or discharge on public health or to identify potential public health problems presented by the release, they present a cognizable claim under $\$ 9607$ (a)..") (emphasis in original). 
3. Difficulties in the Brewer formulation.

Although Brewer makes the better argument, there are problems with awards of medical monitoring costs that the court did not confront. The first difficulty concerns defining the word "monitoring" in a meaningful way. In Coburn v Sun Chemical Corp, the court reviewed many of the key cases and decided explicitly to reject Brewer, ${ }^{90}$ largely on its interpretation of the definition of that term:

[T] he Brewer court's determination that "[p]ublic-health related medical tests and screening clearly are necessary to "monitor, assess, [or] evaluate a release" " contravenes the plain meaning of that phrase. Quite simply, we find it difficult to understand how future medical testing and monitoring of persons ... will do anything to "monitor, assess, [or] evaluate a release" of contamination from the site.

Put more simply, it was unclear to the court in Coburn what medical monitoring is and how it should work. Although Coburn used many of the arguments used in Chaplin ${ }^{92}$ (it appears, for instance, that it mistook medical monitoring for a species of medical treatment), its point is still valid. Before determining whether medical monitoring expenses should be granted, a party must show that these response costs really can be effective. ${ }^{93}$

A second problem that was left unanswered by Brewer is the potential for abuse. It is possible that if medical monitoring expenses are awarded with regularity, parties will begin to sue for monitoring costs as a "back door" method of recovering medical treatment costs under CERCLA. In fact, at least one court has appeared to refuse to award medical expenses for this reason. ${ }^{94}$ Yet an argument based on the potential for abuse is easily countered. First, if this argument holds, it puts awards of all investigatory costs in jeopardy: the potential for fraud or abuse is high in all such cases. More specifically, it is unclear that the risk of abuse is a sufficient reason to limit recoveries; rather, abuse is better controlled by more careful judicial scrutiny. Courts should review the

o0 28 Envir Rptr (BNA) 1665, 1670-71 (E D Pa 1988).

91 Id at 1671.

92 Id at 1670 .

${ }^{03}$ This criterion will be the cornerstone of the test that I will develop in Section V.

-4 Werlein v United States, 746 F Supp 887, 904 (D Minn 1990) (plaintiffs sought costs for monitoring exposure to chemicals; court held that relief sought was "primarily personal treatment for disease"). 
facts carefully, and should allow medical monitoring costs only when they are warranted. ${ }^{95}$

\section{B. Enforcement Anomalies}

Since CERCLA's enactment, the government has initiated most cleanups. This need not be. A change is necessary, in fact, to overcome the myriad problems that the government has had in enforcing CERCLA: budgetary constraints, mismanagement, and general indecision about the Act and environmental law in general. The focus of CERCLA implementation must be moved (at least partially) from the public to the private sector. Medical monitoring costs are an important part of such a shift. Courts should encourage private cleanups as well as testing procedures to facilitate those cleanups. In this way they can counteract the problems in the government's administration of CERCLA.

\section{Enforcement by the EPA.}

Money, of course, is the greatest constraint on the EPA's CERCLA enforcement capabilities. Like many federal agencies, the EPA has been forced to bear part of the burden of the federal deficit by facing budget cuts. During the 1980s the EPA's budgetary problems were enormous. In the middle of the decade its Superfund budget was smaller than in $1981 .{ }^{96}$ In the past three years, the EPA's budget has nominally increased fifty-four percent, but when adjusted for inflation, the agency's overall budget has risen only sixteen percent since 1979-while its workload has doubled. ${ }^{97}$ These budgetary problems make it increasingly onerous for the EPA adequately to enforce CERCLA and other environmental statutes.

A second problem with relying on the EPA to effectuate the cleanup of hazardous waste sites is the attitude that at times may take hold in the agency. For instance, consistent with then-Presi-

\footnotetext{
${ }_{95}$ No court has argued (nor does this Comment) that costs should be granted in a case such as Werlein, where the plaintiffs did appear to be trying to recover medical treatment costs by calling them medical monitoring costs. Werlein arguably is consistent with Brewer and its progeny; it denied response costs simply because they were not warranted on the facts. For more on the problem of untrustworthy medical monitoring claims see Section V.

${ }^{96}$ See Environmental Aspects of President Reagan's Proposed Fiscal 1985 Budget, 14 Envir Rptr (BNA) 1715 (1984). In 1985, the EPA's operating budget was $\$ 1.209$ billion, in contrast to $\$ 1.353$ billion in 1981. Id.

${ }^{87}$ President Bush requested $\$ 1.75$ billion for Superfund for fiscal year 1993. See Brad Knickerbocker, White House Increases Budget, Action On Environmental Issues, Christian Sci Mon 6 (Jan 28, 1992).
} 
dent Reagan's policy of deregulation, the EPA became an agency known for its compromises with and closeness to the industries it is charged with regulating. President Reagan's first EPA administrator, Anne Gorsuch Burford, became infamous as a friend of industry before she unceremoniously stepped down from her post. ${ }^{98}$ More recently, Vice President Quayle's Council on Competitiveness has acted on behalf of the business community to assure that "economic" interests be considered in environmental regulation decisions. Critics charge that EPA administrator William Reilly may have been intimidated into inaction by this group at least once. ${ }^{99}$ With these industry pressures on the EPA, it is difficult for the agency to enforce CERCLA effectively.

A final point that shows that the EPA's enforcement of CERCLA cannot be successful on its own is the small size of the Superfund. Before the 1986 SARA amendments the Superfund contained $\$ 1.6$ billion. This may seem like a great deal of money, but it must be remembered that as of 1985 there were estimated to be 10,000 waste disposal sites that would require as much as $\$ 100$ billion to clean up. ${ }^{100}$ Given these figures, the EPA's mission seems hopeless if it is to clean up all hazardous wastes sites on its own.

2. Enforcement by the ATSDR.

The ATSDR performs health assessments similar to those in medical monitoring suits. ${ }^{101}$ Yet the ATSDR does not fill the need for determining the risks to people's health. Two related factors indicate that private enforcement is an important supplement to the ATSDR's duties if health risks are to be assessed at all hazardous waste sites.

First, for the site-specific assessments required by $\S 104(\mathrm{i})(6)$, the ATSDR's health assessments almost always occur at National Priority List sites at which the EPA is performing or is considering

\footnotetext{
${ }^{98}$ See Superfund II: A New Mandate-A BNA Special Report 9-12 (Feb 13, 1987).

"Dana Priest, Competitiveness Council Suspected of Unduly Influencing Regulators; Secretary Foils Senate Panel's Attempt to Probe Vice President's Group, Wash Post A19 (Nov 18, 1991) (reporting on allegations that Reilly "was forced to withdraw a trash recycling initiative that the council saw as too burdensome to owners and operators of municipal incinerators").

${ }^{100}$ See Philip Shabecoff, Toxic Waste Threat Termed Far Greater Than US Estimates, NY Times 1 (Mar 10, 1985).

${ }^{102}$ See Section II.B.2.
} 
performing a remedial action. ${ }^{102}$ The ATSDR may in its discretion perform assessments at other sites, but it has not. This most likely results from understaffing and budgetary constraints. ${ }^{103}$ So, at smaller sites that are not on the NPL-the very sites at which private parties may consider undertaking removal actions themselves-there is no ATSDR involvement. ${ }^{104}$

A second reason that the ATSDR's work needs to be supplemented by private actions is the agency's preference for assessing broad health concerns over site-specific ones. ${ }^{105}$ In light of the 1986 SARA amendments to CERCLA, the ATSDR has channeled nearly all of its resources into long-term studies, leaving the health effects at smaller sites unstudied. ${ }^{106}$ Thus, there are countless hazardous waste sites for which private testing programs may be the only hope for studying adverse health effects. Because the ATSDR spends most of its resources dealing with broad health testing issues and because the agency views its mandate as involving longterm research, there is room for private parties to monitor health effects as part of removal actions.

This discussion points to an almost inevitable conclusion: If the hazardous waste problem in the United States ever is to be remedied, the focus of CERCLA enforcement must be changed. A mere increase in federal expenditures is not a reliable or likely solution. Similarly, because federal agencies do not always spend wisely the money that is appropriated for them, ${ }^{107}$ increasing their budget may be a waste more than a panacea. Other steps are essential if CERCLA is to be enforced more completely.

${ }^{102}$ The ATSDR "shall consider the National Priorities List schedules and the needs of the Environmental Protection Agency and other Federal agencies pursuant to schedules for remedial investigation and feasibility studies." 42 USC $\$ 9604(i)(6)(C)$.

${ }^{103}$ As of June 1989, the ATSDR received individual requests for site studies forty-nine times; they completed five of those and rejected one; the five they performed were for sites either on, or proposed for, the NPL. See Siegel, 20 Envir L Rptr at 10013 (cited in note 53).

${ }^{104}$ In a recent case, the court refused a medical monitoring claim because $\S 9604(\mathbf{i})(6)(\mathrm{B})$ allows private parties to petition the ATSDR to perform health assessments. Ambrogi $v$ Gould, Inc., 750 F Supp 1233, 1249 (M D Pa 1990). However, the ATSDR may refuse to perform the assessments with a written explanation, and testing contemplated under $\$ 9607$ (a) "is distinct from the health assessment studies available under section 9604(i) [ATSDR] ...." Cook, 755 F Supp at 1474.

${ }^{105}$ See Siegel, 20 Envir L Rptr at 10014-17 (cited in note 53).

${ }^{108}$ Id at 10017.

${ }_{107}$ Associated Press, Overhead Costs Spur Superfund Scrutiny, Chi Trib 8 (Oct 3, 1991) (reporting on EPA investigation reporting "inappropriate" EPA expenditures to contractors performing toxic waste cleanup). 
C. Private Enforcement of Public Rights

1. Private rights of action in environmental statutes.

CERCLA does not give individuals the right to compel federal agencies or private parties to act. ${ }^{108}$ Nevertheless, $\S 107(a)(4)(B)$ of CERCLA does permit parties to clean up hazardous sites on their own, and to recover "costs of response" from responsible polluters. ${ }^{109}$ Other environmental statutes also have private right of action provisions. The Clean Air Act Amendments of $1970^{110}$ and the Federal Water Pollution Control Act (known as the Clean Water Act) Amendments of $1972,{ }^{111}$ for example, contain provisions to supplement agency enforcement with the work of private parties. ${ }^{112}$ Though some commentators maintain that the private enforcement sections of these and other statutes have not been effective, ${ }^{113}$ others argue persuasively that with adjustments, and with a focus on particularly important factors, private rights of action can be a useful tool in environmental cleanups. ${ }^{114}$

\section{Academic views on private enforcement of public law.}

The issue of medical monitoring response costs fits in with a longstanding academic debate over the advisability of private enforcement of publicly-oriented statutes. CERCLA and other envi-

${ }^{108}$ See, for example, Cadillac Fairview/California v Dow Chemical Co., 840 F2d 691, 696-97 (9th Cir 1988) (using structural and expressio unius arguments to deny an extension of the government's right of compulsion under $\S 106$ to private parties suing under $\S 107$ ).

${ }^{100} 42$ USC $\S 9607(\mathrm{a})(4)(\mathrm{B})$.

11042 USC $\$ \S 7401-7642$ (1988 \& Supp 1991). Congress substantially amended the Clean Air Act in 1990, but the amendments did not change the citizen suits provision.

1133 USC $\$ \S 1251-1387$ (1988).

112 For the Clean Air Act, see 42 USC § 7604(a) ("any person" can sue). See also Report of the Committee on Public Works, S Rep No 92-414, 92d Cong, 1st Sess 79 (1971) ("[t]he Committee has established a provision in the bill that would provide citizen participation in the enforcement of control requirements and regulations"). For the Clean Water Act, see 33 USC § 1365(a) ("any citizen" can sue). See also Floor Debate on S 4358, 91st Cong, $2 d$ Sess (Sep 21, 1970), in Cong Rec 32927 (Sep 21, 1970) ("citizens can be a useful instrument for detecting violations and bringing them to the attention of the enforcement agencies and courts alike").

11 See, for example, Adeeb Fadil, Citizen Suits Against Polluters: Picking Up the Pace, 9 Harv Envir L Rev 23, 29-35 (1985) (citizen suits have been uncommon and could be more effective).

11 See, for example, id at 74-82; David Allan Feller, Private Enforcement of Federal Anti-Pollution Laws Through Citizen Suits: A Model, 60 Denver L J 553, 571 (1983) ("As federal enforcement efforts are directed away from the C[lean] A[ir] A[ct] and [the] C[lean] $\mathrm{W}$ [ater] $\mathrm{A}[\mathrm{ct}]$, and the degradation of the environment becomes an expanding threat, the use of citizen suits to enforce anti-pollution laws becomes correspondingly more attractive and feasible."). 
ronmental statutes are easier to construe in this regard than are many other statutes. Because Congress supplied private enforcement provisions in these environmental statutes, there is no need for courts to imply a private right of action under them. The question raised by this Comment-whether CERCLA's private action section should be read broadly to effectuate the Act's purpose by supplementing the efforts of federal agencies-does, however, implicate general questions regarding the public law/private enforcement paradigm.

Professors Richard Stewart and Cass Sunstein have written exhaustively on the pros and cons of private enforcement of public statutes. ${ }^{115}$ They believe that in some ways private enforcement is a "paradox" because agencies are created, in part, to escape "undemocratic" private litigation. ${ }^{116}$ Nevertheless, Stewart and Sunstein conclude that private suits are favorable if two criteria are met and six factors are present. ${ }^{117}$ The two criteria are straightforward. First, the agency must be shown to have devoted inadequate resources to compliance, or simply to lack sanctions to achieve enforcement; second, the cost of private enforcement must not be greater than the cost of agency action. ${ }^{118}$ The six factors that the authors discuss all involve efficiency problems. In particular, the six factors guard against inefficient, "overinclusive" enforcement.119 That is, there is an optimal level of enforcement, above which private actors who supplement agency action actually may prove wasteful. ${ }^{120}$ In such a situation, private enforcement would be unwarranted. Stewart and Sunstein's work is a good framework for deciding whether the private right of action under $\S 107(\mathrm{a})(4)(\mathrm{B})$ of CERCLA should be read broadly, and whether medical monitoring suits should be favored. The next section uses that framework to argue that allowing recovery of medical monitoring response costs would produce a near optimal level of CERCLA enforcement.

\section{Private Suits for Medical Monitoring Costs}

Medical monitoring suits under $\S 107(a)(4)(B)$ meet the criteria developed by Stewart and Sunstein. First, as was argued above,

${ }^{215}$ Richard B. Stewart and Cass R. Sunstein, Public Programs and Private Rights, 95 Harv L Rev 1193 (1982).

116 Id at 1294.

117 Id at 1296-98.

118 Id at 1296.

119 Id at 1307.

${ }^{120}$ Id at 1296-97. 
the EPA and the ATSDR both underenforce their mandates. The policies of and resources available to those agencies make it unlikely that they will effectively clean up hazardous waste sites and sufficiently test for their effects. Second, in the area of medical monitoring, the cost of private enforcement does not exceed the cost of agency action. Not only do private suits for medical testing costs cost less, but they actually may save government money because they do not use the resources of the Superfund.

As for the efficiency factors that must be met to avoid "overenforcement," there are three good reasons to favor recovery of medical monitoring costs. First, although all CERCLA suits involve-to some extent-the environment and human health, medical monitoring suits directly implicate health problems that may already be dangerous and could be getting worse daily. There is an immediate danger in these cases that must be met with vigorous responses. Allowing recovery of private medical monitoring costs-even if it leads to some overenforcement-should be endorsed so as to better protect human life. Yet, as will be shown below, courts will be able to minimize overenforcement difficulties by exercising sound discretion in allowing such claims to go forward.

The second argument in favor of medical monitoring suits (and other prospective recoveries under CERCLA) is efficiency. Testing procedures cost money, but they save money in the long run. When private parties begin removal actions without full information, they may waste time and resources. Medical monitoring may provide the parties with additional, fuller information. Medical monitoring may have another efficiency component as well: every time a person's cancer is spotted at an early stage, the burden of enormous future medical costs may be decreased. Though medical monitoring is an assessment stage in preparation for a removal action, the ancillary effect of saving money in separate damages suits ${ }^{121}$ is not inconsistent with CERCLA's purposes. Private suits for medical monitoring costs thus may be a valuable part of response cost actions and should be favored.

121 The plaintiffs may save the added costs, but more likely the defendants will be spared from state toxic tort litigation for damages. The government saves money as well, both by avoiding the institutional costs of additional litigation and by not having to pay Medicaid or other federally-sponsored medical expenses for those who are not insured, never tested, and not compensated. 
Finally, CERCLA is the result of a congressional policy choice to make cleanup of hazardous wastes the priority. ${ }^{122}$ Congress's choice implies that it considered cost to be only a secondary concern. This means that to some extent slight overenforcement problems could be tolerated. Nevertheless, as will be shown below, ${ }^{123}$ courts are competent to decide on the merits of each case whether a private cleanup is warranted.

All of the criteria and factors of Stewart and Sunstein's paradigm favor reading $\S 107(\mathrm{a})(4)(\mathrm{B})$ of CERCLA to allow recovery for medical monitoring costs. Medical testing can be an effective means of furthering CERCLA's broad public goals that does not lead to "inefficient" enforcement. Private parties that sue for medical monitoring response costs serve the environment and the "public health."

\section{A Test for Evaluating Medical Monitoring Cost Recovery Cases}

The purpose of this final section is to distinguish cases in which medical monitoring costs should be awarded from those cases in which they should not. A medical monitoring program that is carefully constructed to provide information to assist in cleaning up a waste site can be a useful part of a removal action under CERCLA. Recall the complaint in Brewer $v$ Ravan. The plaintiffs in Brewer planned to test the water and soil around the waste site and also intended to monitor the health of the people who lived nearby. The medical monitoring program that withstood a motion for summary judgment was an integral part of the plaintiffs' private removal action. In cases such as Brewer, medical monitoring costs under $\S 107(\mathrm{a})(4)(\mathrm{B})$ of CERCLA ought to be granted.

Yet not all cases are as clear as Brewer. Courts must determine whether individual cases further CERCLA's goals or whether they are redundant actions that do not add to the EPA's and the ATSDR's enforcement potentials. To help courts avoid ad hoc determinations, I suggest the following test, which includes factors courts should consider in deciding whether to permit recovery for medical monitoring costs.

\footnotetext{
${ }^{122}$ See S Rep No 96-848 (cited in note 6).

${ }^{123}$ See Section V.C.
} 


\section{A. Defining Medical Monitoring Costs}

In a medical monitoring cost case, the court must first determine what the plaintiff actually seeks to recover-whether the plaintiff actually seeks medical monitoring costs. This difficulty in characterization plagued the Brewer court's formulation. ${ }^{124}$ The Brewer court noted a difference between costs for "medical testing and screening" and those for "personal injuries or disease," 125 but never mapped out a way to distinguish the two. The court in Coburn criticized Brewer on exactly these grounds, and rejected medical monitoring costs as a viable response cost in part because it felt that a meaningful line could not be drawn. ${ }^{126}$

Private litigants who wish to move forward with suits for medical monitoring response costs should meet three burdens. First, the plaintiffs must demonstrate that a system of testing has been established or is ready for immediate implementation. Then, they must demonstrate that the testing procedures are tailored to determine the effects of substances that are known or suspected to be present at the particular site. They must document the substances at issue and the scientific design of the study to be undertaken. Finally, the parties must be prepared to show that it is the entire community (around the site) that is being tested, not just the named plaintiffs. This last burden protects against charges that only the plaintiffs are profiting from the enterprise. Once these three burdens are met, the court should determine that the costs of response will enable parties to "monitor, assess, and evaluate [a] release or threat of release," 127 and are therefore recoverable.

\section{B. Safeguarding Against Potential Abuse or Inefficiency}

In Werlein v United States, ${ }^{128}$ the court compared cases such as Brewer (that permitted medical monitoring suits to move forward) with those like Coburn (that rejected the claims outright). The Werlein court first argued that it could not "locate any authority" in $\S 107(\mathrm{a})(4)(\mathrm{B})$ to allow medical monitoring as a response cost. ${ }^{129}$ The court equivocated, however, and implied that it

124680 F Supp at 1179 . See text accompanying notes 16-18.

128 Id.

12628 Envir Rptr (BNA) at 1671.

${ }^{127} 42$ USC § 9601(23) (defining "removal"). Once medical monitoring costs are established as consistent with investigatory removal actions, courts will be more likely to grant response costs.

128746 F Supp at 902.

129 Id at 904. 
rejected Brewer because of doubts whether monitoring costs were warranted on the facts at hand.

Werlein shows that a major issue that may drive a court's decision is whether the court perceives that the suit is an attempt to recover medical treatment expenses disguised as a claim for medi'cal monitoring costs. The Werlein court did not go as far as the court in Chaplin, which had held that all medical monitoring suits are veiled attempts to recover treatment costs; it was more discriminating. The court stated that it would consider permitting a medical monitoring suit in other circumstances, but that the plaintiffs before it really sought only expenses for medical treatment. Other courts seem to refuse medical monitoring expenses at least partially out of fear that the plaintiffs are trying to circumvent CERCLA's denial of treatment costs. ${ }^{130}$ An important hurdle for private parties to jump is proving that the suit is not a "backdoor" method of recovering medical treatment expenses.

To guard against this problem, a court must first be sure that the plaintiffs have devised a satisfactory testing program before it permits a medical monitoring cost suit to proceed. ${ }^{131}$ The program must be calibrated to fit an overall removal plan; otherwise the monitoring program could be a ruse. Then the court must determine whether the parties have a reason to use a back-door approach to reimbursement for medical treatment. One reason would be lack of medical insurance, another would be the problems of ongoing and speculative injuries. ${ }^{132}$ With careful scrutiny of the true purposes behind a medical monitoring case, a court need not reject a suit due to lingering doubts about the possibility of abuse.

\section{Inefficient Enforcement}

The final criterion for the propriety of a medical monitoring suit follows from some of the efficiency concerns discussed above. Where the ATSDR and EPA are performing adequately, suits to create private testing programs simply would get in the way or would be duplicative. However, rather than preclude all recoveries out of fears that they may be unnecessary in some situations,

\footnotetext{
130 See, for example, Chaplin, 25 Envir Rptr (BNA) at 2011. Courts that reject medical monitoring claims outright either correctly characterize such costs or believe plaintiffs intend to seek medical treatment costs. See Section IV.A.

131 See Section IV.A.

132 Arguably the harms caused by hazardous wastes always have this effect. However, a court must be prepared to distinguish programs that are designed to provide treatment from true monitoring programs that are connected to removal actions.
} 
judges should focus on the case at hand. If the ATSDR is establishing a testing program and the EPA is planning to clean up the site, it is not likely that private actions will be brought; pending suits will be dropped. Courts should look carefully at the facts at hand and dismiss a case for overlapping enforcement only when that problem actually exists.

\section{Conclusion}

This Comment has demonstrated that CERCLA provides for a private right of action whose use is both consistent with the Act's purposes and useful for enforcing the Act's broader goals. The Comment has shown that the private suit for medical monitoring costs (which often is misunderstood to be a suit for medical treatment costs) is an important tool for the private litigant. Medical monitoring is an efficient use of private resources that can supplement public implementation of CERCLA. Judges should understand that sometimes an individual's trip to the doctor may benefit us all. 
